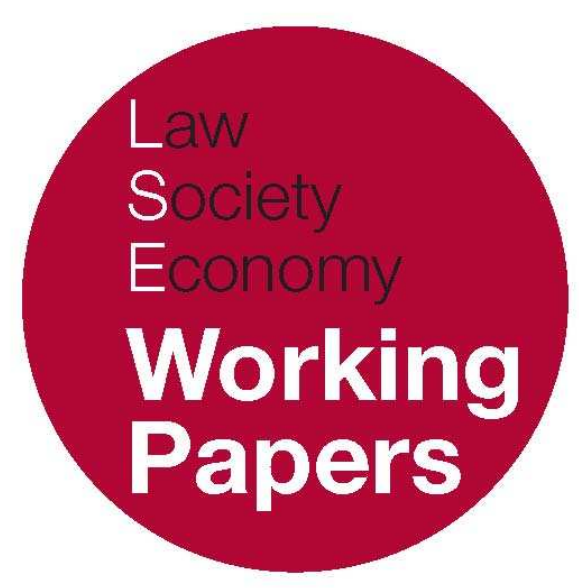

\title{
Two Directives, Two Politics - Prospects for the EU ETS
}

\author{
Andrés Jonathan Drew \\ LSE Law, Society and Economy Working Papers 11/2010 \\ London School of Economics and Political Science \\ Law Department
}

This paper can be downloaded without charge from LSE Law, Society and Economy Working Papers at: www.lse.ac.uk/collections/law/wps/wps.htm and the Social Sciences Research Network electronic library at: http://ssrn.com/abstract=1618876.

(C) Andrés Jonathan Drew. Users may download and/or print one copy to facilitate their private study or for non-commercial research. Users may not engage in further distribution of this material or use it for any profit-making activities or any other form of commercial gain. 


\title{
Two Directives, Two Politics - Prospects for the EU ETS
}

\author{
Andrés Jonathan Drew*
}

\begin{abstract}
The allocation rules for phase one EU ETS emissions permits demonstrates that energy generators were lobbying winners because they successfully blocked differential treatment from energy intensive industries, who cannot pass-on real or nominal costs of permits to consumers. The application of public choice theory predicted free allocations to industry, but failed to anticipate windfall profits for energy generators. In phase three, the reverse is true; energy intensive industries successfully established differential rules. These rules provide them with free allocations while most energy generators will be subject to 100 per cent auctioning. Public choice theory also failed to predict these changes. This paper presents the argument that a shift in Wilson's Typology from client to interest group politics explains this change in allocation rules. This dynamism in Wilson's Typology is demonstrated by comparing the positions of industry associations representing energy generators and energy intensive industries with the two directives before and after consultations, which facilitates the identification of lobbying winners and losers. The EU ETS case study is fertile ground for testing regulatory theories that explain shifts away from clientelist policies and towards more optimal policy equilibriums. This paper provides both a theoretical framework and empirical evidence for how emissions trading policy can be improved, despite rent-seeking, once it clears the legislative hurdle.
\end{abstract}

\footnotetext{
* BA, LLB, BCL (McGill), MSc (LSE); Researcher in the Law Department, London School of Economics and Political Science. This publication is based on my dissertation for the M.Sc. Regulation program at the London School of Economics which I completed in September 2009.
}

I am very grateful to Professor Robert Baldwin for valuable comments on a previous draft of this paper. 


\section{PART ONE: INTRODUCTION}

Emissions trading (ET) is an important regulatory instrument to address climate change because it is said to be efficient, effective, and equitable. ${ }^{1}$ While all three claims are subject to criticism, this paper uses the European Emissions Trading Scheme's (ETS) regulatory failures as a case study because it is the first of its kind and provides valuable policy lessons for ET programs elsewhere. ${ }^{2}$ Specifically, industry lobbying for free European Union Allowances (EUA) in phase one (20052007) and phase two (2008-2012) has been criticised for creating windfall profits benefiting electricity generators (generators) and raising electricity prices for both domestic consumers and energy intensive industries (EIIs). However, phase three (2013-2020) allocation rules require 100 per cent auctioning for most generators and free permits for some EIIs.

Table Two below explains that phases one and two were the product of the same directive and consultation process. Phase one is now complete which provides a rich source of empirical evidence and academic literature. Phase three, however, was subject to a separate directive and consultation process. References to phases one and three throughout this paper also refer to their enabling directives unless otherwise specifically stated.

The puzzle is: what explains the change in permit allocation rules between ETS phases one and three? In particular, as actor preferences have not significantly changed and most private interest theories of regulation predict the static dominance of producer interests at the expense of diffuse cost-bearing publics, why did this shift take place?

This paper will argue that Wilson's politics of regulation Typology is more applicable to EU policymaking than private interest theories and that, within EU policymaking, a shift has taken place that is consistent with a movement that Wilson would typify as a change from client politics to interest group politics. ${ }^{3}$ This Wilsonian shift usefully explains the change in EUA allocation rules between ETS phases one and three.

The ETS is an interesting case study because it demonstrates the possibility of policy shifts that can be captured within the terms of Wilson's Typology. Such changes, moreover, can be tracked evidentially. The ETS consultation process for phases one and three directives was transparent. All lobbying positions are available on the EU Commission's (commission) website. EURELECTRIC represented generators in both phases. EIIs lobbied mainly individually in phase

\footnotetext{
1 N. Stern, Blueprint for a Safer Planet: How to Manage Climate Change and Create a New Era of Progress and Prosperity (London: The Bodley Head, 2009).

2 R. Baldwin, 'Regulation Lite: The Rise of Emissions Trading' (2008) 2 Law and Financial Markets Review 3, 262. Regulatory failures are defined as: 'a regulation with a purpose to improve the world but which fails to produce a net benefit to society' in C. Sunstein, 'Paradoxes of the Regulatory State' (1990) 57 University of Chicago Law Review 407, 412.

${ }^{3}$ J.Q. Wilson, The Politics of Regulation (New York: Basic Books, 1980).
} 
one, but formed the Alliance of Energy Intensive Industries (AEII) in phase three. Comparing the positions of these associations with the original commission proposals and final directives in both phases allows, with certain assumptions, for the identification of lobbying winners and losers. The results of this analysis will then be matched with Wilson's typological descriptions to show that his theory provides a better explanation for the change in allocation rules.

As Wilson predicted greatest rent-seeking with client politics, conclusions will assess the prospects of ETS reflecting optimal policy prescriptions. ${ }^{4}$ These conclusions may be of significance to policymakers designing American, Australian, and global ET schemes.

\section{PART TWO: UNDERSTANDING ALLOCATIONS}

Relatively few scholars have applied private interest theories to ET schemes, and even fewer have used Wilson's Typology. The literature also struggles to explain changes in allocation rules between phases. Although some scholars apply Wilson's Typology to analyse American $\mathrm{SO}_{2}$ trading and ETS phase one, to date none have applied Wilson's Typology to phase three's final EUA allocation. ${ }^{5}$ While a number of authors have explained free over-allocation of EUAs in phase one, none predicted the windfall profits of generators or considered potential changes in allocation methods after $2012 .^{6}$

This section will assess the relevance of private interest theories to this topic, particularly their applicability to EU policymaking and their ability to explain regulatory change. The case will then be made for using Wilson's approach instead.

\footnotetext{
4 See section 'What prospects for phase three?' below.

${ }^{5}$ P.L. Joskow and R. Schmalensee, 'The Political Economy of Market-Based Environmental Policy: The U.S. Acid Rain Program' (1998) 41 Journal of Law and Economics 37; L. Heinzerling, 'Selling Pollution, Forcing Democracy' (1995) 14 Stanford Environmental Law Journal 300; B.J. Cook, 'The Politics of Allowance Allocation in Emissions Trading Systems: Implications for Climate Change Policy Design' (unpublished working paper, 2009) 1. For ETS phase three, J. Wettestad, 'EU Energy-Intensive Industries and Emissions trading: Losers Becoming Winners' (2009) 19 Environmental Policy and Governance 309 , the author analysed the phase three commission proposal, not the final directive, and did not use Wilson's Typology.

${ }^{6}$ J.T. Boom, 'Interest Group Preference for Instruments of Environmental Policy: An Overview' in C. Bohringer, M. Finus, and C. Vogt. (eds), Controlling Global Warming: Perspectives from Economics, Game Theory, and Public Choice (Cheltenham: Edward Elgar, 2002); P. Markussen and G. T. Svendsen, 'Industry Lobbying and the Political Economy of GHG Trade in the European Union' (2005) 33 Energy Policy; G.T. Svendsen, 'Lobbying and CO2 Trade in the EU' in B. Hansjurgens (ed), Emissions Trading for Climate Policy: US and European Perspectives (Cambridge: Cambridge University Press, 2005).
} 


\section{PRIVATE INTEREST THEORIES AND EMISSIONS TRADING}

\section{Private interest theories and the policymaking process}

Private interest theories all highlight the risks of capture caused by information asymmetry and revolving door career paths. ${ }^{7}$ While modern versions of these theories now explain business preference for ET, historically they predicted the dominance of command and control regulation. ${ }^{8}$ Both analyses point to potential rent-seeking with either instrument resulting from Hayek's 'knowledge problem' of insurmountable informational asymmetries.? More recently, scholars have signalled the importance of market-based instruments (MBI) like carbon taxes or ET to reduce this asymmetry and discourage 'revolving door' career paths that contribute to capture. By choosing ET instead of best available technology mandates, or cap and trade systems rather than baseline and credit approaches, asymmetry and the potential for capture is reduced. ${ }^{10}$ Despite the theoretical foundations of various private interest approaches, there exists little empirical evidence to support either capture or revolving-door careers. ${ }^{11}$ Government failure has also been criticised as a myth. ${ }^{12}$

There are two dominant schools of private interest theories, each with different assumptions about actor motivation. The Chicago school of law and economics believes legislators and regulators seek to maximise their personal wealth. Virginian public choice scholars assume that in addition to financial interests, these actors are motivated by electoral and ideological gains. In both models, regulatees seek to extract rents (excess profits) caused by government intervention in the economy (eg limiting competition by awarding monopolies or creating other barriers to market entry). ${ }^{13}$ Despite the strong empirical evidence for private interest theories, they have been criticised for a lack of applicability to EU policymaking and a failure to adequately explain policy change.

\footnotetext{
7 Defined as when: 'vested interests bias the incentives of regulators and governments to act in their interests rather than the broader public interest'. See D. Helm, 'Regulatory Reform, Capture and the Regulatory Burden' (2006) 22(2) Oxford Review of Economic Policy 169.

8 n 6 above; J.M. Buchanan and G. Tullock, 'Polluters' Profit and Political Response: Direct Control vs. Taxes' (1975) 65(1) The American Economic Review 139.

${ }^{9} \mathrm{n} 2$ above; F.A. Hayek, Law, Legislation and Liberty : A New Statement of the Liberal Principles of Justice and Political Economy (London: Routledge \& Kegan Paul, 1982); G. Tullock, 'The Welfare Coasts of Tariffs, Monopolies, and Theft' (1967) 5 Western Economic Journal 224. Hayek's critique of central planning is conceptually different from public choice, because it does not assume policymakers are motivated by selfinterest. See M. Pennington, Planning and the Political Market: Public Choice and the Politics of Government Failure (London: Athlone, 2000) 11.

${ }^{10} \mathrm{n} 2$ above, 263; n 7 above, 180.

${ }^{11}$ E. Bo, 'Regulatory Capture: A Review' (2006) 22(2) Oxford Review of Economic Policy 203, 215.

12 P.J., Boettke, C.J. Coyne, et al, 'Saving Government Failure Theory from Itself: Recasting Political Economy from an Austrian perspective' (2007) 18 Constitutional Political Economy 127, 135.

${ }^{13}$ R. Baldwin and M. Cave, Understanding Regulation: Theory, Strategy, and Practice (Oxford: Oxford University Press, 1999) 22.
} 


\section{The limits of private interest theories}

\section{EU policymaking}

Foster reveals the challenges of applying Chicagoan and Virginian theories to EU policymaking through his analysis of network industry ownership in Britain. ${ }^{14}$ In rejecting a Chicagoan explanation for nationalisation, he describes the centrality of pork-barrel lobbying to Chicagoan models. ${ }^{15}$ The Chicagoan approach is therefore more applicable to political systems like America with liberal campaign finance laws, weak political parties, and first-past the post-electoral systems, a combination rarely found in Europe. ${ }^{16}$ Following an intergovernmentalist approach to EU policymaking, member states, and therefore European institutions, are less exposed to Chicagoan arguments. ${ }^{17}$ For example, the EU Parliament (parliament) cannot initiate legislation and is elected by proportional representation, and other EU institutions are not directly elected. Parliament also operates by consensus through transnational groupings and is therefore less exposed to capture in the Chicagoan sense. ${ }^{18}$ This likely explains why parliament has always favoured EUA auctioning. ${ }^{19}$

At first glance, Virginian explanations are more convincing. However, following a supranationalist argument, the commission dominates and is the locus for most lobbying activity. ${ }^{20}$ It seeks neither electoral nor ideological gains in the Virginian sense because it is an unelected bureaucracy. The commission is not motivated by ideology but by Brussels empire-building, jurisdictional expansionism, and budget maximisation through regulation. ${ }^{21}$ Authors have highlighted the growth and domination of interest group activity by corporate interests in Brussels and how the commission gives insider status to business and funds groups - non-governmental organisations (NGOs) - that provide informational support for its agenda of European integration. ${ }^{22}$ This provides a severe challenge to private interest theories because it reverses the direction of capture. Part Four will discuss evidence of this in ETS phase three.

${ }^{14}$ C. Foster, 'Rival Explanations of Public Ownership, Its Failure and Privatization' (1994) 72)(4) Public Administration 489.

15 ibid, 497.

${ }^{16}$ C. Hood, Explaining Economic Policy Reversals (Buckingham: Open University Press, 1994) 26.

17 A. Moravcsik, 'Preferences and Power in the European Community: A Liberal Intergovernmentalist Approach' (1993) 31(4) Journal of Common Market Studies 473; A. Moravcsik, The Choice for Europe. Social Purpose and State Power from Messina to Maastricht (London: Routledge, 1998).

18 A. Michaelowa, 'Impact of Interest Groups on EU Climate Policy' (1998) 8 European Environment 152, 157.

${ }^{19}$ Markussen and Svendsen, $\mathrm{n} 6$ above, 253.

${ }^{20}$ G. Majone, 'The Rise of the Regulatory State in Europe' (1994) 17(3) West European Politics 77, 85; G.T. Svendsen, The Political Economy of the European Union: Institutions, Policy and Economic Growth (Cheltenham: Edward Elgar, 2003) 66.

${ }^{21}$ Svendsen, ibid, 131.

${ }^{22}$ For example, ibid, 93; Svendsen, n 6 above, 154, where the author posits that centralised policymaking at the commission makes lobbying cheaper than more fragmented polities like America. See, also, C. Mahoney, 'The Power of Institutions State and Interest Group Activity in the European Union' (2004) 5(4) European Union Politics 441, 443; D. Coen, 'Empirical and Theoretical Studies in EU Lobbying' (2007) 14(3) Journal of European Public Policy 333, 341; M. Braun, 'The Evolution of Emissions Trading in the European Union-The Role of Policy Networks, Knowledge and Policy Entrepreneurs' (2008) Accounting, Organisations and Society (doi:10.1016/j.aos.2008.06.002). 


\section{Explaining policy change}

The Chicago school struggles to explain policy change more than other regulatory theories. ${ }^{23}$ If regulation is a function of client politics (see Table One), then what explains policy reversals that reduce rents like full EUA auctioning?24 While Chicagoans such as Peltzman, Keeler, and Noll have argued that endogenous processes of 'rent dissipation' cause shifts to deregulation, evidence of this phenomenon is patchy. ${ }^{25} \mathrm{In}$ addition, no risk of windfall profit dissipation exists for generators because the industry is not exposed to global competition. Virginian theories better explain change because the utility functions of politicians are broader; they are motivated by ideological gains and shifting voter preferences. ${ }^{26}$ Therefore, electoral backlashes (against producer dominance) or 'new ideas' are endogenous to Virginian theory and can explain deregulation. ${ }^{27}$ While other regulatory theories such as pluralism and institutionalism are important to understand policy dynamism, a discussion of them is beyond the scope of this paper. Instead, the following analysis will consider the dominant literature: public choice application to ETS phase one. ${ }^{28}$

\section{Public choice application to emissions trading}

Most literature applies public choice to ET because it reveals the risks of regulatory failure. Unless planners have sufficient incentives to act on and acquire the necessary information to correct market failures, it is a 'nirvana fallacy' to assume that politics can fix markets. ${ }^{29}$ Political markets are mired with transaction costs and collective action problems that generate client politics equilibriums. ${ }^{30}$ The rational ignorance of voters provides little incentive for monitoring or mobilising against rent-seeking by small, wealthy, organised lobby groups. ${ }^{31}$ Politicians and bureaucrats are monopolists in their domains and have strong incentives to make short-term gains through rent distribution and to empire-build with clientelist

23 n 16 above, 27.

24 K. Neuhoff and F.C. Matthes 'The Role of Auctions in Emissions Trading' (Climate Strategies Working Paper, Cambridge, UK: Climate Strategies, 2008) 4.

25 S. Peltzman, 'The Economic Theory of Regulation after a Decade of Deregulation' (Brookings Papers on Economic Activity, Washington: Microeconomics, 1989); T. Keeler, 'Theories of Regulation and the Deregulation Movement' (1984) 44(1) Public Choice 103; R.G. Noll, 'Economic Perspectives on the Politics of Regulation' in R. Schmalensee and R.D. Willig (eds), Handbook of Industrial Organisation (New York: Elsevier, 1989); n 16 above, 32.

26 This is a strength rather than a weakness in terms of loss of predictive power which Baldwin and Cave argue, $\mathrm{n} 13$ above, 25.

${ }^{27}$ Keeler, n 25 above, 130; n 14 above, 501.

28 A.S. MacFarlane, 'Interest Groups and Political Time: Cycles in America' (1991) 21(3) British Journal of Political Science 257; M. Schneiberg, 'Combining New Institutionalisms: Explaining Institutional Change in American Property Insurance’ (2005) 20(1) Sociological Forum 93.

${ }^{29}$ H. Demsetz, 'Information and Efficiency: Another Viewpoint' (1969) 12 Journal of Law and Economics 1 , 1; Pennington, n 9 above, 7 .

30 Pennington, ibid, 17.

31 M. Olson, The Logic of Collective Action: Public Goods and the Theory of Groups (Oxford: Oxford University Press, 1965); I. Somin, 'Voter Ignorance and the Democratic Ideal' (1998) 12(4) Critical Review 413. 
coalitions. ${ }^{32}$ Such has been the strength of rent-seeking in both America and Australia that ET programs have failed to clear legislative hurdles in both countries (see the section on Policy implications below). Indeed, America has abandoned the more efficient economy-wide cap and trade program in favour of a sectoral approach, with ET primarily for electric utilities. ${ }^{33}$

Public choice literature defines the self-interests of large emitters (large electricity generators, EIIs), politicians, environmental NGOs (ENGOs), and bureaucrats in a consistent way. Generally speaking, large emitters are profit maximisers with goals to minimise climate policy costs and/or gain additional rents. This explains their preference for ET compared to carbon taxes. ${ }^{34}$ Within this group, large electricity producers in Europe and America favour grandfathered permits. ${ }^{35}$ Elected politicians (parliament and council) are assumed to be risk-averse opportunists with a primary objective of re-election. ${ }^{36}$ ENGOs have historically focused on targets and not policy instruments because they raise funds through easily understandable campaigns. ${ }^{37}$ However, significant literature exists analysing the preference and opposition of ENGOs to MBIs and ET in particular. ${ }^{38}$ Bureaucrats (commission) prefer instruments that allow discretionary decisions, require negotiation and are based on special information needs. This allows them to empire-build by budget-raising, to link climate policy with other growth areas, and to play a central role in implementation. ${ }^{39}$ It also demonstrates a bias towards the conservatism of command and control regulation. ${ }^{40}$ These defined interests allow public choice theory to identify whether groups are winners or losers in political markets. Markussen and Svenden identified winners and losers for Directive one, while Wettestad did so for Commission Proposal Two (see Table Two for details of these documents). ${ }^{41}$

With these interests in mind, public choice theory has made a number of predictions that have been confirmed by empirical evidence to explain why ET is counterproductive and deviates from economic prescriptions. ${ }^{42}$ For example,

\footnotetext{
32 J.M. Buchanan and G. Tullock, The Calculus of Consent : Logical Foundations of Constitutional Democracy (Ann Arbor: University of Michigan Press, 1962).

${ }^{33}$ US Congress-Senate. American Power Act. Discussion Draft. 111 th Cong., $2^{\text {nd }}$ sess. (May 2010) 1-987 at http://kerry.senate.gov/americanpoweract/pdf/APAbill.pdf (last visited 15 May 2010).

${ }^{34}$ n 2 above, 264.

35 G.T. Svendsen, Public Choice and Environmental Regulation: Tradable Permit Systems in the United States and CO2 Taxation in Europe (Cheltenham: Edward Elgar, 1998) 119.

36 Boom, n 6 above, 220.

${ }^{37} \mathrm{n} 18$ above, 158.

38 S. Kelman, What Price Incentives? Economists and the Environment (Boston, Mass.: Auburn House, 1981); N.O. Keohane, R.L. Revesz, et al, 'The Positive Political Economy of Instrument Choice in Environmental Policy' (Discussion Paper 97-25, Washington D.C.: Resources for the Future, 1997); B.R. Dijkstra, The Political Economy of Environmental Policy: A Public Choice Approach to Market Instruments (Cheltenham: Edward Elgar, 1999); Svendsen, n 35 above.

${ }^{39} \mathrm{n} 18$ above, 156; Svendsen, n 20 above, 107.

40 Boom, $\mathrm{n} 6$ above, 235.

${ }^{41}$ Markussen and Svendsen, $\mathrm{n} 6$ above; Wettestad, n 5 above.

42 R.W. Hahn, 'Economic Prescriptions for Environmental Problems: How the Patient Followed the Doctor's Orders' (1989) 3(2) The Journal of Economic Perspectives 95; P. Grabovsky, 'Counterproductive Regulation' (1995) 23 International Journal of the Sociology of Law 347.
} 
public choice predicts that the preferences of small, powerful, cohesive industry lobbies will be reflected in permit allocation rules (free grandfathering) and abatement levels (lower). Empirically, the American $\mathrm{SO}_{2}$ trading scheme and the ETS evidenced this phenomenon. ${ }^{43}$ At an international level, business preferences are reflected in the Kyoto Protocol Joint Implementation and Clean Development Mechanism. ${ }^{44}$ The large gap between the ambition of international agreements and the reality of domestic implementation can also be explained by the relatively greater strength of climate protection interests at the international level. ${ }^{45}$ Finally, the divergence between mandatory ET legislation in Europe and America or Australia can be partly explained by the commission's self-interest in institutionalising the ETS. ${ }^{46}$

While these failures cannot be disputed, ETS phase three is an improvement on phase one. Public choice struggles to explain this phenomenon because actor preferences have not significantly changed (see Case Study Analysis below). The commission always favoured auctioning, and industry always preferred free permits. Even while EIIs objected to generator windfall profits they favoured free allocation for themselves and demanded compensation for higher energy prices. EURELECTRIC also begrudgingly accepted auctioning in phase three (see Table Six in Appendix One). Wilson's Typology and derived literature provide a better analytical framework for explaining different allocation rules. This last discussion will complete the literature review.

\section{WILSON'S TYPOLOGY}

Wilson's Typology is a political rather than economic explanation for regulation. It complements public choice theory by providing a profile for successful rent-

\footnotetext{
${ }^{43}$ Heinzerling, n 5 above; Joskow and Schamalensee, n 5 above; N. Anger, C. Bohringer, et al, 'Public Interest vs. Interest Groups: Allowance Allocation in the EU Emissions Trading Scheme' (ZEW Discussion Paper No 08-023, Mannheim, Germany: Center for European Economic Research, 2008); H. Tschochochei and J. Zockler, 'Business and Emissions Trading from a Public Choice Perspective-Waiting for a New Paradigm to Emerge' in R. Antes, B. Hansjurgens, and P. Lamathe (eds), Emissions Trading: Institutional Design, Decision Making and Corporate Strategies (New York: Springer, 2008).

${ }^{44}$ J.T. Boom and G.T. Svendsen, 'The Political Economy of International Emissions Trading Choice: Empirical Evidence' (Discussion Paper 00-19, Copenhagen: Institute of Economics, University of Copenhagen, 2000); R. Falkner, Business Power and Conflict in International Environmental Politics (Basingstoke: Palgrave Macmillan, 2008) 122.

45 n 18 above; Falkner, ibid; A. Michaelowa 'Climate Policy and Interest Groups-A Public Choice Analysis' (1998) November/December Intereconomics 251.

46 Svendsen, n 20 above; J.A. Layzner, 'Deep Freeze: How Business has Shaped the Global Warming Debate in Congress' in M.E. Kraft and S. Kamienieck (eds), Business and Environmental Policy: Corporate Interests in the American Political System (Cambridge, Mass: MIT Press, 2007); M. McKenzie, 'Lessons for Australia from the European Union Emissions Trading Scheme' (2008) 5 Macquarie Journal of International Comparative Environmental Law 115. For a good analysis of how business preferences in Washington and Brussels led to different policy outcomes, see Braun, n 22 above; C. Egenhofer, 'The Making of the EU Emissions Trading: Scheme: Status, Prospects and Implications for Business' (2007) 25(6) European Management Journal 453.
} 
seeking groups instead of simply assuming regulation is demanded and obtained. ${ }^{47}$ Wilson's theory does not explain how benefits materialise because unlike Virginians and Chicagoans, Wilson ignores the consideration for regulatory bargains. ${ }^{48}$ The Typology therefore suffers from a critique of generality, but is also more applicable to EU policymaking. The essence of Wilson's argument is that the distribution of regulatory costs and benefits is central to predicting rent-seeking levels. Wilson's Typology also provides roles for policy entrepreneurs, force of ideas, and other political explanations for regulatory change, because costs and benefits are not exclusively monetary. The importance of economic interests differs throughout Wilson's theory. ${ }^{49}$

Wilson's Typology describes four politics of regulation. When benefits of regulation are concentrated and costs are dispersed, client politics (the Chicagoan original sin) emerges with very high levels of rent-seeking because cost-bearers face high barriers to collective action due to group size..$^{50}$ The general public (often cost-bearers) may not be aware of clientelist regulation because negotiations are usually opaque. However, NGOs are now important checks on this phenomenon.

Less favourable conditions for rent-seeking are expected in the following three circumstances. Firstly, when costs and benefits of regulation are concentrated, interest group politics emerges, meaning that regulation will benefit one group at the expense of another. Each side has an incentive to organise and exercise political influence with less rent-seeking resulting. While the public may sympathise with one group over another, its voice only is heard in general terms. In the second circumstance, costs and benefits are both dispersed, and all or most of society expects to both gain and pay. As such, both opponents and proponents of regulation may find it difficult to organise. A majoritarian politics will therefore emerge only when popular sentiment and elite opinions are convinced of regulatory benefits. Lastly, entrepreneurial politics occurs when the benefits of regulation are dispersed but the costs are concentrated. In this situation, opponents have strong incentives to block regulation. Yet even Wilson observed how policy entrepreneurs can mobilise latent public support despite collective action challenges. Table One illustrates Wilson's Typology with examples: ${ }^{51}$

\footnotetext{
${ }^{47}$ n 16 above, 24; n 13 above, 24.

48 Noll, n 25 above, 1277.

${ }^{49} \mathrm{n} 3$ above, 361-372.

50 Olson, n 31 above.

51 n 3 above, 365-372.
} 
Table One: Wilson's typology - the politics of regulation ${ }^{52}$

\begin{tabular}{|c|c|c|}
\hline \multirow{2}{*}{$\begin{array}{c}\text { Benefits of } \\
\text { Regulation }\end{array}$} & \multicolumn{2}{|c|}{ Costs of Regulation } \\
\cline { 2 - 3 } Concentrated & Interest Group Politics & Dispersed \\
& $\begin{array}{c}\text { Example: rail freight rate } \\
\text { regulation }\end{array}$ & $\begin{array}{c}\text { Example: } \text { restrictions on } \\
\text { imports }\end{array}$ \\
\hline Dispersed & Entrepreneurial Politics & $\begin{array}{c}\text { Majoritarian Politics } \\
\end{array}$ \\
& $\begin{array}{c}\text { Example: restrictions on tobacco } \\
\text { sales }\end{array}$ & $\begin{array}{c}\text { Example: public smoking } \\
\text { bans }\end{array}$ \\
\hline
\end{tabular}

Wilson's typology and emissions trading

To the author's knowledge, only three articles analyse ET regimes with Wilson's Typology and none compare changes between ETS phases one and three. ${ }^{53}$ Joskow and Shmalensee concluded that free allocations in the American $\mathrm{SO}_{2}$ trading scheme generated majoritarian politics because costs and benefits were widely distributed instead of weighted toward narrow economic or geographical interests. ${ }^{54} \mathrm{~A}$ majoritarian equilibrium is synonymous with climate policy goals which: (1) internalise carbon costs so that they are borne by all carbon-intensive consumers; and (2) spread the benefits of climate stability widely. Patashnick draws the same conclusions to theorise why such general interest reforms are sustained. ${ }^{5}$ However, both these analyses overlook how ET works in practice; some firms profited by passing-on costs while others could not. Cook's working paper instead characterises the $\mathrm{SO}_{2}$ trading program as interest group politics because the final directives pleased each affected party. ${ }^{56}$ His analysis also finds evidence of interest group politics in ETS phase one because industries received free EUAs and competed for both exclusion and lower abatement targets. However, Cook does not address the issue of generator windfall profits in phase one, nor does his analysis extend to phase three which requires full auctioning for generators and free permits for most EIIs. ${ }^{57}$ Part Four below explains how these omissions are important counter-arguments to Cook's characterisation of phase

\footnotetext{
52 Source: Adapted from Hood, n 16 above, 25.

53 See n 5 above.

54 n 5 above, 70,81 .

55 E.M. Patashnik, Reforms at Risk: What Happens After Major Policy Changes are Enacted (Princeton: Princeton University Press, 2008) 153-154. General interest reforms are defined by Patashnik on page 2 as 'nonincremental change of an existing line of policymaking intended to rationalize governmental undertakings or to distribute benefits to some broad constituency'. Therefore Patashnik's conception is very similar to Wilson's entrepreneurial and majoritarian politics.

56 n 5 above, 13.

57 ibid, 16.
} 
one. This supports the paper's hypothesis that phase one was an example of client not interest group politics.

\section{Explaining regulatory change using Wilson's typology}

Wilson's Typology adds to existing ETS public choice literature because it better explains changes across phases. By recasting Svendsen and Cook's work in terms of client politics and analysing recent scholarship by Wettestad and Gullberg, who use EU theories to demonstrate that EIIs won in phase three, valuable insights can be gained. ${ }^{58}$ This paper will apply Wilson's Typology to both final ETS directives to explain different EUA allocation rules.

Wilson provides little explanation for shifts in his typology except for the possibility of entrepreneurial politics. He believes policy entrepreneurs are facilitated by crises and by the discovery of electoral ore from regulation that benefits scattered groups at the expense of narrow ones. ${ }^{59}$ Keeler, Bendor, and Moe make this argument to explain deregulation. ${ }^{60}$ However, Wilson is unclear as to whether entrepreneurial politics means blank slate regulation (new) or changes to regulation formed in client or interest politics equilibriums to reflect a new alignment of costs and benefits. His rather static view of cost-benefit distribution suggests the former, and therefore Wilson does not explain how regulation escapes the iron grip of client politics.

A small but fascinating body of scholarship develops Wilson's Typology to explain these changes; some of which was canvassed above (see Explaining policy change). Hood divides the literature between exogenous (force of ideas) and endogenous (interest group) explanations, although as discussed above, ideas are not necessarily exogenous to Wilson's model. For example, the very prescriptive success of Chicagoan theories may have undermined their descriptive accuracy through exogenous new ideas (regulatory failure) which facilitated shifts from client to entrepreneurial politics. ${ }^{61}$ Adding to Peltzman and Keeler's endogenous arguments analysed above, Hood describes a 'lose-to-win' strategy adopted by AT\&T in accepting deregulation for access to new markets. ${ }^{62}$ Also, countermobilisation occurred when corporate consumers lobbied for deregulation of telecommunications markets to lower costs and compete with other financial centres. However, Hood explains that counter-mobilisation cuts both ways and

\footnotetext{
${ }^{58}$ Svendsen, n 20 above; Svendsen n 6 above; ibid; Wettestad, n 5 above; A.T. Gullberg, 'The European Electricity Sector and the EU ETS Review' (CICERO Working Paper 2008:01, Oslo: Center for International Climate and Environmental Research, 2008).

${ }^{59}$ Policy entrepreneurs are characterised as: well-educated, understanding complex ideas, having high social status and opinion-leadership. See J. Black, 'Tomorrow's Worlds: Frameworks for Understanding Regulatory Innovation' in J. Black, M. Lodge, and M. Thatcher (eds), Regulatory Innovation: A Comparative Analysis (North Hampton, MA: Edward Elgar, 2005) 18-20; n 3 above, 370-371.

${ }^{60}$ Keeler, n 25 above, 130; J. Bendor and T. M. Moe, 'An Adaptive Model of Bureaucratic Politics' (1985) 79(3) The American Political Science Review 755, 768.

${ }^{61} \mathrm{n} 16$ above, 28-29; M. Derthick and P.J. Quirk, The Politics of Deregulation (Washington, DC: Brookings Institution, 1985)

62 n 25 above; $n 16$ above, 30 .
} 
can cause a shift back from entrepreneurial to client politics. ${ }^{63}$ The tendency of client politics to self-destruct may also explain shifts to interest group equilibriums, although very little literature explores this point. The case study analysis in Part Four below explores this self-destructive pattern in the ETS.

New scholarship provides explanations for the rise and sustainability of general interest reforms. ${ }^{64}$ Patashnik surveys the literature and outlines three conditions for adoption: (1) policy entrepreneurs must lower information costs to mass publics by linking reform solutions to salient issues (eg by linking ET to GHG mitigation policy); (2) reform proponents must adopt procedural strategies to weaken the organisational advantages of narrow groups (eg by developing expert knowledge or changing committees structures); and lastly (3) reform advocates must use tactical concessions to neutralise political opposition (eg by providing free permits). ${ }^{65}$ Patashnik then argues that general interest reforms are most resilient when they upset coalitional patterns and stimulate the emergence of new vested interests and political alliances. This last point is significant because one of the advantages of ET compared to carbon taxes is that the former is easier to implement politically because policymakers can pay-off opponents and create new political constituencies that have a stake in ET programs. ${ }^{66}$ However, somewhat paradoxically, this virtue can be a vice if rent-seeking is so strong that stakeholders lose faith in ET, resulting in a failure to implement in the first place. This phenomenon is currently being observed in both America and Australia.

In light of the literature, this paper addresses the following puzzle: what explains the different EUA allocation rules for generators and EIIs between ETS phases one and three? The proposed and tested hypothesis is: a shift can be seen in Wilson's Typology, as one from client politics to interest group politics. This shift explains the change in allocation rules.

\section{PART THREE: A SHORT HISTORY OF THE EU ETS}

The ETS is the cornerstone of EU climate policy. Launched in 2005, it is the first cross-border greenhouse gas emissions (GHG) trading scheme and regulates more than 11,500 installations or about 45 per cent of total $\mathrm{EU} \mathrm{CO}_{2}$ emissions. ${ }^{67}$ Phase one ran from 2005 to 2007, while phase two runs from 2008-2012. The EU

\footnotetext{
63 n 16 above, 33 .

${ }^{64}$ See n 55 above.

65 ibid, ch 2.

66 ibid, 144; J.P. Voß, 'Innovation Processes in Governance: The Development of 'Emissions Trading' as a New Policy Instrument' (2008) 34(5) Science and Public Policy 329, 338; n 2 above. For example, carbon markets create a powerful and rapidly growing set of vested financial interests with strong incentives to lobby for the continuation of the ETS. Also, ring-fencing auctioning revenues for renewable energy projects create new political constituencies.

67 Egenhofer, n 46 above, 453.
} 
directive (Directive One) that enabled both these phases fell under the co-decision mechanism and entered into force on 13 October 2003. ${ }^{68}$ It was legislated after the Council of Ministers (council) unanimously modified Commission Directive One, along with a very large majority in parliament. ${ }^{69}$

Directive One was the result of rigorous commission consultations with stakeholders. The Green Paper provided the reference for this. In only a few cases did the commission express explicit preferences (see Table Six below in Appendix One). ${ }^{70}$ Article 30 of Directive One required that the commission submit a report to parliament and council before extending the directive the Kyoto Protocol expires (phase three: 2013-2020).71 The report assessed ETS performance and concluded the need for a review. This gave rise to a number of position papers and studies by stakeholders with further consultations within the European Climate Change Program (ЕCCP). The ECCP established a working group on the review and produced final reports incorporated into a commission communication. ${ }^{72}$ Membership of the working group was comprised of member states, industry, NGOs, academia, and research institutes. These consultations formed the basis of a second commission directive (Commission Directive Two). ${ }^{73}$ It was modified into Directive Two, which was adopted unanimously by the council with only 60 votes against and 29 abstentions in parliament. ${ }^{74}$ Directive Two entered into force on 5 June 2009. Table Two provides a legislative timeline.

\footnotetext{
68 Parliament and Council Directive (EC) 2003/87, Establishing a Scheme for Greenhouse Gas Emission Allowance Trading Within the Community and Amending Council Directive 96/61/EC [2003] OJ L275/32.

69 Commission (EC), 'Proposal for a Directive of the European Parliament and of the Council Establishing a Scheme for Greenhouse Gas Emission Allowance Trading with the Community and Amending Council Directive 91/61/EC' COM (2001) 581 final, 23 October 2001; Egenhofer, n 46 above, 454 .

${ }^{70}$ Commission (EC), 'Greenhouse Gas Emissions Trading Within the European Union' (Green Paper) COM (2000) 87 final, 3 March 2000.

${ }^{71}$ Commission (EC), 'Communication from the Commission to the Council, the European Parliament, the European Economic and Social Committee and the Committee for the Regions: Building a Global Carbon Market -Report Pursuant to Article 30 of Directive 2003/87/EC' (Communication) COM (2006) 676 final, 13 November 2006.

72 ibid.

${ }^{73}$ Commission (EC), 'Proposal for a Directive of the European Parliament and of the Council Amending Directive 2003/87/EC so as to Improve and Extend the Greenhouse Gas Emission Allowance Trading System of the Community' (Communication) COM (2008) 16 final, 23 December 2008.

${ }_{74}$ Parliament and Council Directive (EC) 2009/29 amending Directive 2003/87/EC so as to Improve and Extend the Greenhouse Gas Emission Allowance Trading Scheme of the Community [2009] OJ L140/63; Euractiv.com, 'Mixed Reactions as Parliament Approves EU Climate Deal' (18 December 2008) at http://www.euractiv.com/en/climate-change/mixed-reactions-parliament-approves-eu-climatedeal/article-178163 (last visited 20 May 2010).
} 
Table Two: EU ETS legislative history

\begin{tabular}{|l|l|}
\hline Phase one & Green Paper (2000) \\
\cline { 2 - 2 } (2005-2007) & Green Paper Consultation (2000) $)^{75}$ \\
\cline { 2 - 2 } Phase two & Commission Directive one (2001) \\
\cline { 2 - 2 }$(2008-2012)$ & Directive one (2003) \\
\hline $\begin{array}{l}\text { Phase } \\
\text { three } \\
(2013-2020)\end{array}$ & $\begin{array}{l}\text { Commission Report to Parliament and Council pursuant to Art. } 30 \text { of } \\
\text { Directive one (2006) }\end{array}$ \\
\cline { 2 - 2 } & Commission Report Consultations (2007)77 \\
\cline { 2 - 2 } & Commission Directive two (2008) \\
\cline { 2 - 2 } & Directive two (2009) \\
\hline
\end{tabular}

Multiple purposes prevent labelling ETS phase one an overall regulatory failure. ETS phase one was a trial period with a goal to ensure European leadership promoting global cost-effective climate policy instruments. ${ }^{78}$ This leadership component has been accomplished; however, a complete regulatory success would have resulted in the absence of both windfall profits and over-allocation. ${ }^{79}$ This is significant because ETS phase three will not require 100 per cent EUA auctioning. The potential for regulatory failure still exists. As a result, many commentators propose a carbon tax as an alternative policy tool because it is less susceptible to rent-seeking and provides price stability. ${ }^{80}$ The next section presents the evidence and indentifies winners and losers in both ETS phases.

75 DG Environment, 'Answers to Green Paper from National Governments, Business, Business Associations and NGOs' (2000) at http://ec.europa.eu/environment/docum/0087_en.htm (last visited May 20, 2010).

76 Commission (EC), 'Building a Global Carbon Market - Report Pursuant to Article 30 of Directive 2003/87/EC’ (Communication) COM (2006) 676 final, 13 November 2006.

77 DG Environment, 'Emission Trading System (EU ETS) Stakeholders' Contributions for the Review Process of the EU ETS (publication subject to agreement)' (2007) at http://ec.europa.eu/environment/climat/emission/list_review.htm (last visited 20 May 2010).

78 A.D. Ellerman and P.L. Joskow 'The European Union's Emissions Trading System in Perspective' (2008) May Policy 1.

${ }^{79}$ See ibid; windfall profits occurred because very little EUA auctioning occurred in ETS phases one and 2, and allocations were based on the historical emissions of each installation. Energy generators incorporated the nominal prices of EUAs in their rates despite receiving them for free. Over-allocation resulted because of the decentralised allocation system which provided member states with incentives to protect national industries. Modest emissions targets, data constraints, and the political challenges of forecasting economic growth all contributed to the EUA price crash in 2006.

80 n 2 above; C. Hepburn, 'Carbon Taxes, Emissions Trading and Hybrid Schemes' in D. Helm and C. Hepburn (eds), The Economics and Politics of Climate Change (Oxford: Oxford University Press, 2009); D. Helm, 'Carbon Taxes' (London: Policy Exchange, 2010, forthcoming). 


\section{EVIDENCE ANALYSED}

The industries analysed are limited to large electricity generators and EIIs. It is clear from the literature review that generators on balance won in phase one, while EIIs won in phase three. ${ }^{81}$ This paper seeks to explain the reasons for this change.

The positions of individual firms and NGOs are also not analysed.82 Instead, the interests of large generators are reflected in EURELECTRIC's positions. The AEII represented 12 energy intensive industrial sectors (most EIIs) in phase three but not phase one. A full list is found in Appendix Two. The AEII was created after the relative failure of its members' lobbying and previous weaker umbrella groups' efforts (UNICE, IFIEC) in phase one.

The lobbying positions of EURELECTRIC and the AEII in phases one and three are represented in Tables Four and Five. Table Six compares the Green Paper to Directive One, while Table Seven compares Commission Directive Two to Directive Two. Table Four illustrates the divided positions of EII members during phase one. All tables are found in the appendices.

\section{IDENTIFYING WINNERS AND LOSERS}

Adding to the findings of Markussen and Svendsen, Tables Four, Five and Six indicate that phase one did not produce absolute winners despite some sectors faring better than others. ${ }^{83}$ All industrial sectors wanted a voluntary system, which Directive One rejected. Only chemical and aluminium industries successfully lobbied for exclusion. They claimed the ETS would affect their ability to compete internationally. Free grandfathered EUAs are an example of cross-sectoral success particularly when compared to auctioning. However, the divisions of AEII members on this issue are glaring. It may explain their inability to oppose allocation and banking decisions left to member states which created the competitiveness problems discussed above in the first section of Part Three ${ }^{84}$ Generators on the other hand favoured national allocations because it allowed consideration (ie lobbying) of national differences in reduction potential, despite their numerous cheap options for $\mathrm{CO}_{2}$ reductions compared to EIIs. ${ }^{85}$ Finally, by

\footnotetext{
81 All interviews; Gullberg, n 58 above; Wettestad, n 5 above; EndsReport 'Trading Down to a LowCarbon Economy' (2009) 408 Ends Report 38.

$82 \mathrm{BP}$ and Shell were instrumental in institutionalising the ETS because they had significant experience with their own internal emissions trading schemes and provided great informational resources to the commission. The literature review above also mentions the significance of NGOs. See Braun, n 22 above, 13; J.B. Skjærseth and J. Wettestad, EU Emissions Trading: Initiation, Decision-Making and Implementation (Aldershot.: Ashgate, 2008) 184.

83 Markussen and Svendsen, $n 6$ above, 253; Skjærseth and Wettestad, ibid.

84 P.D.R. Gonzalez, 'Implementing the EU Emissions Trading Directive in Spain: A Comparative Study of Corporate Concerns and Strategies in Different Industrial Sectors' in R. Antes, B. Hansjurgens, and P. Letmathe (eds), Emissions Trading and Business (New York: Physica-Verlag, 2007) 311; Skjærseth and Wettestad, ibid, 116; EndsEurope, 'EU Climate Policy Package Delayed' (17 October 2001) at http://www.endseurope.com/5841?referrer=search (last visited May 20, 2010).

85 S. Varming, P. B. Eriksen, et al, 'Tradable CO2 Permits in Danish and European Energy Policy' (RisoR-1184(EN), Roskilde: Riso National Laboratory, 2000); n 78 above, 32.
} 
avoiding auctioning, generators reaped windfall profits. The fact that EIIs did not identify this issue, promote auctioning for generators, or obtain compensation for higher energy prices is further evidence that generators fared better than most EIIs in phase one. Markussen and Svendsen attribute this success to generators being the largest and most important sector for implementation. ${ }^{86}$

Like phase one, phase three did not produce absolute winners; however, Table Seven demonstrates EURELECTRIC did not receive the lions' share of concessions. The electricity industry gained only one important victory in Directive Two - that of optional derogations for generators in Poland and the Baltic. This is limited to a high percentage of fossil fuel generation and interconnectivity with Russian energy alternatives (see Article 10(c) in Table Seven). Despite the apparent coup, it is not attributable to EURELECTRIC's position. Instead it reflects the unique characteristics of these domestic energy markets and the symbolic goal of political unanimity at the council for Poznan Conference of the Parties (COP) $14 .{ }^{87}$ It is a mere 'fig leaf according to one EU insider because the qualifying threshold for derogations is very high. ${ }^{88}$

AEIIs on the other hand, received every concession except one - that of regulating electricity costs (see Table Seven). However, Directive Two, Article 10(a) allows member states to compensate industries for GHG cost pass-through, with admittedly very strict benchmarks. This is nevertheless an improvement on Commission Proposal Two, which omitted the issue. The AEIIs also improved Commission Proposal Two by increasing the number of small installations excluded from the ETS and adding a qualitative criterion to the methodology for identifying industries at risk of carbon leakage. ${ }^{89}$

Wettestad and Gullberg both argue that when analysed through the lens of industry differentiation, it is clear that EURELECTRIC won in phase one, and AEIIs won in phase three..$^{90}$ By differentiation, Wettestad means electricity generators can pass-on real or nominal costs of EUAs without risk of carbon leakage or displacement, while some EIIs cannot because they are exposed to global competition..$^{11}$

\footnotetext{
86 n 6 above, 253.

87 Commission interviews; EndsReport, 'Compromise EU Climate Package Hurried Through Brussels Summit' (2008) 407 Ends Report 4, 4.

${ }^{88}$ Commission interviews.

${ }^{89}$ Commission interviews; Directive Two, n 74 above, Art 10(a), (c) and Annex II. Carbon leakage is defined in $\mathrm{n} 72$ above as: 'relocating of GHG activities from the EU to third countries, thereby increasing global emissions.' Some Baltic generators are exposed to carbon leakage because of their interconnectivity and competition with Russian energy suppliers. They therefore cannot pass-on nominal or real EUA costs (interview); see also: EndsEurope, 'Baltic States to Link up with Wider EU Grid' (18 June 2009) at http://www.endseurope.com/21597? referrer=search (last visited 20 May 2010).

90 n 5 above; $n 58$ above.

${ }^{91}$ Industry interviews; Grabovsky, n 42 above, 351; J.D.C.D. Larragan, 'Too Much Harmonisation? An Analysis of the Commission's Proposal to Amend the EU ETS from the Perspective of Legal Principles' in M. Faure and M. Peeters (eds), Climate Change and European Emissions' Trading: Lessons from Theory and Practice (Cheltenham: Edward Elgar, 2008) 74.
} 
The next and final section will attempt to provide a theoretical framework for explaining this change in winners and losers between phases one and three using Wilson's Typology.

\section{PART FOUR: CASE STUDY ANALYSIS}

\section{THE EXPLANATORY FORCE OF WILSON'S TYPOLOGY}

This paper seeks to understand: why different EUA allocations rules were adopted in ETS phases one and three. As addressed in Part Two above, most private interest theories struggle to provide an explanation of this shift because actor constellations and their interests have not significantly changed. Yet the ETS case study identified generators as lobbying winners in phase one, while EIIs won in phase three. The hypothesis defended here is that a shift from client to interest group politics from phase one to phase three explains this change. Before testing and drawing inferences from this hypothesis, two questions must be addressed: (1) do the case study facts fit with Wilson's Typology? and (2) why did interest group politics not emerge in phase one?

On balance, evidence for phase one fits with Wilson's description of client politics. Small, well-organised generators successfully secured free EUAs and passed-on their nominal costs to diffused domestic consumers, generating significant windfall profits. However, two facts do not fit this model: (1) allocation rules were transparently devised; and (2) powerful EIIs could have ensured the emergence of interest group politics. Wilson envisaged client politics as one of 'backstairs intrigue, quiet lobbying, and quick passage with a minimum public discussion'. ${ }^{2}$ Nothing about the ETS legislative process is further from that expectation. Also, public interest arguments about climate change mitigation are the reason for these directives, which Wilson believed would require 'more elaborate justifications - and thereby mobilize a more extensive coalition'. 93 The other three politics envisage greater transparency or at least some public knowledge of the rents being lobbied for. This is because majoritarian politics require public support for adoption, while entrepreneurial politics require policy entrepreneurs to mobilise latent public sentiment. Interest group politics expect a lukewarm public whose voices are heard in 'weak or general terms'.94 Consequently, while the case study evidence prevents any serious characterisation of phase one as either majoritarian or entrepreneurial politics, it does present the following question: why did interest group politics not emerge in the first place?

\footnotetext{
${ }^{92} \mathrm{n} 3$ above, 369.

93 ibid, 370.

94 ibid, 368.
} 
As discussed in Part Two, Cook has characterised phase one as interest group politics. ${ }^{95} \mathrm{He}$ concludes that evidence of interest group competition fits Wilson's prediction because something in the 'final legislation please[d] each affected party'. ${ }^{96}$ These points are difficult to dispute. However, resulting windfall profits for generators do not fit with lower rent-seeking expectations of interest group politics, nor does the fact that eventual ET regulatory costs are borne by all carbon-intensive consumers (not just EIIs). Rather, these facts fit with client politics. Moreover, if interest group politics emerged in phase one, why did the allocation rules change in phase three? This form of politics expects only marginal changes due to fierce competition.

Cook's analysis overlooks at least three important factors that help explain why interest group politics did not emerge in phase one: (1) the windfall profit mechanism was not widely understood or made transparent by generators; (2) EIIs were divided and not well-organised; and (3) the legislative process was rushed with steep learning curves for most involved. Each of these factors will be discussed in turn.

Ellerman and Joskow argue that 'the effects of the ETS on wholesale and retail power prices and generator profitability when the sector was being liberalized were not widely understood'. ${ }^{97}$ This is supported by the fact that no reference to potential windfall profits exists in the very comprehensive Green Paper. ${ }^{98}$ On the other hand, greater profitability for low-carbon generators (nuclear, hydro) in liberalised markets was expected because wholesale market prices reflect EUA values. However, these installations received few or no permits. ${ }^{99}$

In addition, not everyone at the commission understood the risk of windfall profits. The DG Enterprise and Industry, whose stakeholders are the EIIs, remained unaware of this risk until late in the negotiation process. Only through piecing together evidence about price interaction with marginal power plants did EIIs become aware of windfall profits risks. ${ }^{100}$ Individual interviews suggest that in hindsight, 'the commission was naïve to not recognize why EURELECTRIC supported the ETS'. ${ }^{101}$ On the other hand, the DG Environment was 'probably aware' as an official there argues that:

windfall profits were understood from a textbook perspective only. The commission did not understand how it worked in practice. For example, which firms are price makers or takers and how it would equalize across sectors or how liberalization would put a downward pressure on this

95 n 5 above, 16-17.

${ }^{96} \mathrm{n} 3$ above, 368 .

${ }^{97} \mathrm{n} 78$ above, 27.

98 n 70 above, s 7.3 .

${ }^{99}$ Egenhofer, $\mathrm{n} 46$ above, 457.

100 Commission interviews.

101 ibid. 
phenomenon $[\ldots]$ competitiveness was the most important issue for lobbyists in phase one, not windfall profits. ${ }^{102}$

The DG Energy and Transport was most aware of this risk, because their stakeholders are the generators, but all interviewees persist that requiring higher auctioning levels for generators "was part of the compromise required for implementation'. ${ }^{103}$

Generators likely understood they would benefit from windfall profits. EURELECTRIC carried out ET simulations in 1999 and 2000 where its members presumably learned about windfall profits. ${ }^{104}$ An official at EDF confirms this and acknowledges that generators anticipated windfall profits. ${ }^{105}$ However, another official at the same company argues that 'free allocations were introduced primarily to minimize the competitiveness impacts on coal rather than nuclear generators'. ${ }^{106}$

EIIs were not well-organised in phase one. Markussen and Svendsen draw this conclusion as do Engenhofer and Wettestad. ${ }^{107}$ Wettestad argues that 'they woke up and got their ETS act together' after phase one, becoming more knowledgeable, united and improving their standing within the commission. ${ }^{108}$ This is evidenced by their role in establishing and dominating the High Level Group ${ }^{109}$, their active participation in the ECCP110 meetings, and their multitargeted lobbying drive in phase three.111 All three activities ensured the impossibility of ignoring windfall profits and carbon leakage. In contrast, during phase one ECCP meetings, EIIs were uncoordinated and partly disagreed amongst themselves. One observer likened it to 'having slept in class'. ${ }^{112}$ This conclusion is

\footnotetext{
102 ibid.

103 ibid.

104 Braun, n 22 above, 13.

105 Industry interview.

106 ibid.

${ }^{107}$ C. Egenhofer, 'Anxiety Prevails as Windfall Benefits Power Companies' (European Voice, 2005) at http://www.europeanvoice.com/article/imported/anxiety-prevails-as-windfall-benefits-powercompanies/51479.aspx (last visited 20 May 2010); n 6 above, 255; n 5 above, 311.

108 Wettestad, n 5 above; industry interviews. For example, the EEF commissioned an independent study on the effects of carbon leakage for the British steel industry.

109 The High Level Group on Competitiveness, Energy and the Environment was established in 2006 as a follow-up to the October 2005 communication on Industrial Policy, see Commission (EC), 'Implementing the Community Lisbon Programme: A Policy Framework to Strengthen EU Manufacturing-Towards a More Integrated Approach for Industrial Policy' (Communication) COM (2005) 474 final, 5 October 2005. It consists of member state representatives and various bodies representing industrial energy producers and consumers, and ENGOs. Wettestad, n 5 above, 314, and Gullberg, $\mathrm{n} 58$ above, 3, both argue the group was dominated by energy intensive industries.

110 This group was the primary institution for stakeholder input in ETS phases one and three. In phase three, EIIs outnumbered generators for ECCP membership by three to one; they also became important sources of information to the commission, particularly regarding the impact of electricity and carbon prices on competitiveness and how to calculate firms at significant risk of carbon leakage. See Wettestad, ibid, 311-313.

111 Corporate Europe Observatory, 'Watering Down the EU's Climate Policies a Multi-Pronged Corporate Attack' (December 2008) at http://archive.corporateeurope.org/docs/climatelobby2008.pdf (last visited 20 May 2010); Wettestad, n 5 above, 317; EndsReport, n 81 above.

112 Wettestad, ibid, 315.
} 
also strengthened by the EII's divisions in Tables Four and Five and the frequency of AEII press releases after Directive One was legislated (more than 10 were issued after January 2004 and none before that date). ${ }^{113}$

ETS phase one was a quick policy-making process guided by the principle of implementability where groups with knowledge and experience with ET had stronger lobbying power. After the withdrawal of America from the Kyoto Protocol in 2001, the commission embarked on a learning, consultation, and implementation sprint to establish the ETS in four years. This was part of its strategy to replace America as climate change policy leader.114 Phase one ECCP meetings were dominated by generators because they provided the commission with information on how ET worked. ${ }^{115}$ Officials interviewed at the commission all posit that phase one was a trial period; the most important goal was to get things started because it triggers a learning process and institutionalises the regime. Avoiding the American fate, where business blocked mandatory carbon regulation, was high on policymakers' minds. ${ }^{116}$ Confronting lobby groups on allocation methods risked closing the commission's implementation window. It also would have detracted from the herculean tasks of technical forecasting and data collection necessary for market creation and to negotiate National Allocation Plans. ${ }^{117}$

The core of Wilson's argument is that the distribution of costs and benefits of regulation explains levels of rent-seeking. While ETS phase one had all the characteristics of being an example of an interest group battle, it appears from this case study that costs and benefits do not operate in a vacuum. They need to be transparently understood, and interest groups also need time to mobilise. In this sense, there are informational costs and transaction costs to collective action that provide certain interest groups with lobbying advantages. These costs can be significant and explain why Wilson's Typology does not always match the empirical reality. Nevertheless, this insight fits with Wilson's typology if regulatory costs and benefits are conceived of more broadly to include: transaction, informational, agency, and collective action costs and benefits.

In summary, although phase one does not neatly fit in either client or interest group politics, the argument presented here is that client politics arguments are strongest. The next section will analyse whether phase three corresponds with Wilson's description of interest group politics.

\footnotetext{
${ }^{113}$ See press releases in Appendix Two below.

114 A.C. Christiansen and J. Wettestad, 'The EU as Frontrunner on Greenhouse Gas Emissions Trading: How Did it Happen and Will the EU Succeed?' (2003) 3(1) Climate Policy 3, 4; J. Wettestad, 'The Making of the 2003 EU Emissions Trading Directive: An Ultra-Quick Process Due to Entrepreneurial Proficiency' (2005) 5(1) Global Environmental Politics 1, 17-19.

115 Braun, n 22 above, 12.

116 Layzner, n 46 above, 105.

117 M. Grubb and F. Ferrario, 'False Confidences: Forecasting Errors and Emission Caps in CO2 Trading Systems' (2006) 6 Climate Policy 495, 495; n 78 above, 7-11.
} 


\section{EXPLAINING SHIFTS: CAN REGULATORY FAILURES BE CORRECTED?}

ETS phase three can be characterised as interest group politics because the final legislation pleased each affected party and resulted from competition between active and knowledgeable interest groups. ${ }^{118}$ For instance, EURELECTRIC remained very active but understood windfall profits would end after phase two although it did not endorse auctioning. Instead, its achieved message was that other sectors should not unduly benefit from free allocations. ${ }^{119}$ As in phase one, the process was transparent, but this time public opinion clearly sided with EIIs because global competition risks and public outrage over higher energy prices, with corresponding profits, received headlines. ${ }^{120}$ The level of overall rent-seeking in phase three matches interest group politics expectations: auctioning removes windfall profits for generators, and the exceptions for facilities in Eastern Europe use strict benchmarks, while the free-allocations for EIIs are also very restrictive.

At present, the impacts of ET policies are understood by broad constituencies, and the first signs of entrepreneurial or majoritarian politics may be appearing. The allocation rules are moving towards optimal policy prescriptions which disperse both costs and benefits of regulation (Wilson's majoritarian politics). As such, consumers pay the final costs, and no industry unduly benefits. Nevertheless, this majoritarian equilibrium is taking an entrepreneurial route because, depending on which EIIs qualify for free EUAs in phase three, some may bear the complete cost of regulation while all dispersed consumers may benefit from lower emissions. The ETS will eventually become majoritarian. However, this prospect is likely longer-term because full carbon-cost internalisation (with costs born fully by carbon-intensive consumers) is only expected if and when carbon targets tighten through 2020 and beyond. Also, future generations (not current cost-bearers) will benefit from climate stability if targets are overshot.121

Other than the greater organisation, cohesion, and resources of EIIs, ETS case study facts in phase three match the theoretical explanations for shifts away from client politics surveyed in the literature review (see Part Two above). For example, exogenous shifts in the form of global competition raised the profile of carbon leakage facing EIIs. ${ }^{122}$ Indeed, Wettestad argues that windfall profits on their own did not justify different allocation rules between industries. ${ }^{123}$ Rather, it was the combination with fears of carbon leakage that facilitated regulatory change. In addition, the importance of auctioning as a policy instrument to remove windfall

\footnotetext{
118 Industry interview.

${ }^{119}$ Commission and industry interviews.

120 Wettestad, n 5 above, 316; Business and Enterprise Committee, 'Energy Prices, Fuel Poverty and Ofgem' HC (2007-08) 293-I, at

http://www.publications.parliament.uk/pa/cm200708/cmselect/cmberr/293/293i.pdf (last visited 20 May 2010).

$121 \mathrm{n} 1$ above, 26.

122 eg AEII press releases in Appendix Two below.

123 n 5 above, 317.
} 
profits may have operated as a 'force of idea'.124 Elements of client politics' tendency for self-destruction are also visible because high-profile windfall profits and resulting higher electricity prices were bound to create a backlash.

The ETS case study matches Patashnick's three conditions for policy reform. The first condition, that policy entrepreneurs lower information costs, was present in the form of NGOs, EIIs, and the media, who explained the link between prices and windfall profits. ${ }^{125}$ Consumers also painfully felt the impact of higher energy prices. The second condition, procedural strategies to weaken vested interests, existed as new working groups were created with greater weight given to EIIs. Finally, the third condition of tactical concessions is seen in the commission's strategy to neutralise ET opposition. In phase one, it secured the support of the largest emitting group, through free permit allocations. In phase three, it developed formulas to allocate free EUAs to EIIs and to compensate them for higher energy costs. Generators may have also adopted a lose-to-win approach by accepting auctioning because they will pass-On EUA costs to consumers and can potentially price the lost profits (from no windfall profits). ${ }^{126}$ This strategy could also be motivated by fear of future profit regulation. ${ }^{127}$ The ETS has clearly disrupted traditional coalitional partners and stimulated the emergence of new vested interests, for example: the EIIs that benefit from free permits, the generators that have invested heavily in abatement and can bank excess permits between phases, and the specialised businesses that provide financial services for the development and maintenance of carbon markets.

One important counter-argument to this analysis is that interest group politics may have emerged in phase one if the risk of windfall profits was widely understood. In other words, using this case study to develop theoretical shifts in Wilson's Typology is pointless (at least for a shift from client to interest group politics) because but for the misrepresentation of generators, interest group politics would have emerged in the first place. This implies phase three is simply a correction to intended equilibriums of small groups bearing both costs and benefits of regulation. As discussed above, evidence supports a case for this position, because EIIs would likely have mobilised earlier. However, this is a counter-factual argument. ${ }^{128}$ We simply will never know whether mobilisation would have occurred. Moreover, this argument overlooks how the ETS was a new untested policy. It also minimises the important lessons to be drawn from the processes by which ET policies are initiated and reach general interest equilibriums (entrepreneurial or majoritarian politics).

\footnotetext{
124 Commission (EC), 'Question and Answers on the Commission's Proposal to Revise the EU Emissions Trading Scheme' (Memorandum) MEMO/08/35, 23 January 2008; n 78 above, 30 ; n 24 above, 5 .

125 See AEII press releases in Appendix Two below for evidence of their policy entrepreneurship.

126 Commission interviews.

127 Wettestad, n 5 above.

128 J.D. Fearon, 'Counterfactuals and Hypothesis Testing in Political Science' (1991) 43(2) World Politics 169
} 


\section{THEORETICAL IMPLICATIONS}

This case study provides evidence for and adds to the sparse literature on theoretical explanations for shifts in Wilson's Typology, particularly shifts from client to interest group via entrepreneurial and finally majoritarian politics. It also demonstrates an interesting narrative that is testable against other policy reform case studies. That is, when new transparent public interest policies are proposed with interest group politics potential but majoritarian policy prescriptions, and where informational asymmetry (expertise) exists between regulated groups (or one group is more instrumental for policy institutionalisation), client politics is likely to emerge. This is likely to occur even if all groups appear to benefit equally before the policy is implemented. However, once one group realises that others have benefited more, the self-destruction process of client politics triggers a counter-mobilisation by losers. Demands for rents in the second round of rulemaking will also be met by greater resistance. This is because the reform is embedded by having already upset existing coalitional patterns and created new vested interests that understand the potential for further rent-seeking. Therefore, not only is there a return to interest group politics, but also strong indications of a tendency towards entrepreneurial or majoritarian politics as the rules begin to resemble optimal policy prescriptions. Table Three illustrates this narrative:

Table Three: The direction and prospects of optimal policies in Wilson's typology 129

\begin{tabular}{|c|c|c|}
\hline \multirow{2}{*}{$\begin{array}{c}\text { Benefits of } \\
\text { Regulation }\end{array}$} & \multicolumn{2}{|c|}{ Costs of Regulation } \\
\hline Concentrated & Interest Group Politics & \multicolumn{2}{c|}{ Dispersed } \\
\cline { 2 - 3 } & & \\
\hline Dispersed & Entrepreneurial Politics \\
(General Interest) & Majoritarian Politics \\
(General Interest)
\end{tabular}

129 Source: Adapted from Hood, n 16 above, 25. 


\section{WHAT PROSPECTS FOR PHASE THREE?}

It is too early to predict a self-correction from past disorders. The above discussion assumes less regulatory failures in phase three; specifically that recipients of free permits will not accrue windfall profits. However, existing literature that suggests carbon leakage risks are overstated is a serious cause for concern. ${ }^{130}$ A thorough analysis of this issue is beyond the scope of this paper, but it is worth briefly outlining the debate here. For example, a report by Oxford Economics predicts that moving to 100 per cent auctioning with a carbon price of $€ 25 /$ ton will cut EU GDP by 0.5 per cent in the medium to long term. ${ }^{131} \mathrm{~A}$ more moderate analysis by the Carbon Trust concludes that only cement, steel, and aluminium sectors are exposed. ${ }^{132}$ Others such as the IPCC, Wooders, et al, and Mattoo, et al, believe that carbon leakage will only have minimal effects. ${ }^{133}$ For example, Barker, Junankar, et al believe the impacts will be similar to variations in exchange rates. ${ }^{134}$ Indeed Reinaud found no ETS impact on carbon leakage, and a recent report by Climate Strategies warns of future regulatory failures with free allocations to EIIs. ${ }^{135}$ Other risks include the economic and political fallout of border taxes on the carbon footprints of imports to prevent carbon leakage. ${ }^{136}$

Quantifying carbon leakage is challenging, particularly because member states will push for protecting domestic industry, and evidence is only certain once displacement occurs. ${ }^{137}$ This is confirmed by the final list of exposed industries, which contains more than conservative prescriptions recommend. ${ }^{138}$ Therefore, the risk of windfall profits in phase three has not disappeared; indeed it may have increased since the failure to reach a robust international agreement at

\footnotetext{
${ }^{130}$ EndsReport, 'What Price the Cost of Carbon?' (2007) 394 Ends Report 32.

131 Oxford Economics, Report on Modelling the Macroeconomic Competitiveness Impacts of EU Climate Change Policy (London: Oxford Economics, 2007) 4.

132 Carbon Trust, EU ETS Impacts on Profitability and Trade: A Sector by Sector Analysis (London: Carbon Trust, 2007) 1; industry interview.

133 IPCC, 'Summary for Policymakers' in B. Metz, O.R. Davidson, P.R. Bosch, R. Dave, and L.A. Meyer (eds), Climate Change 2007: Mitigation. Contribution of Working Group III to the Fourth Assessment Report of the Intergovernmental Panel on Climate Change (Cambridge: Cambridge University Press, 2007) 12; P. Wooders, A. Cosbey, et al, Border Carbon Adjustment and Free Allowances: Responding to Competitiveness and Leakage Concerns (Paris: OECD, 2009); A. Mattoo, A. Subramanian, et al, Reconciling Climate Change and Trade Policy (Washington: World Bank, 2009).

${ }_{134}$ T. Barker, S. Junankar, et al, 'Carbon Leakage from Unilateral Environmental Tax Reforms in Europe, 1995-2005' (2007) 35 Energy Policy 6281, 6291.

135 J. Reinaud, 'Issues Behind Competitiveness and Carbon Leakage: Focus on Heavy Industry' (IEA Information Paper, Paris: International Energy Association, 2008) 2; S. Droge, 'Tackling Leakage in a World of Unequal Carbon Prices' (Climate Strategies Working Paper, Cambridge, UK: Climate Strategies, 2009) 6.

136 Economist, 'Green with Envy: The Tension Between Free Trade and Capping Emissions' (19 March 2009) The Economist, A. Gurría, 'Carbon Has No Place in Global Trade Rules' (5 November 2009) Financial Times.

${ }^{137}$ Industry interview.

138 Commission (EC), 'Decision Determining, Pursuant to Directive 2003/87/EC of the European Parliament and of the Council, a List of Sectors and Subsectors Which are Deemed to be Exposed to a Significant Risk of Carbon Leakage' (Decision) 2010/2/EU, 24 December 2009.
} 
Copenhagen did not trigger the review clause (of the list) in Article 10(a) of Directive Two. ${ }^{139}$ The debate over windfall profits and carbon leakage is likely to intensify in the literature and until an international agreement is concluded.140 A senior official at the commission recognises that carbon leakage is not 'a serious problem, but the process was highly politicized and lobbied. The best can be the enemy of the good and sufficient safeguards like strict benchmarking exist to minimize problems'. Such pragmatism and optimism in politics is normal. However, there is evidence that the benchmarking process currently underway is also subject to gaming. ${ }^{141}$ This is a shame, because the excesses of small powerful groups at the expense of wider populations may lead to counter-excess - the potential abandonment of a useful regulatory tool (ET) for climate change mitigation.

\section{POLICY IMPLICATIONS}

The ETS case study provides further evidence that it is possible to escape the iron clutches of client politics. It instructs policymakers to potential ET regulatory failures, particularly in relation to free grandfathered allocations. ${ }^{142}$ It also provides short and long-term strategies for ET institutionalisation and demonstrates the prospects for equilibriums at optimal policy prescriptions. However, as already noted, if phase three suffers from regulatory failures, the prospects for a rising phoenix may be delayed.

This paper highlights important considerations for American and Australian policymakers who are currently negotiating climate change mitigation policies. Proposals for ET schemes in these countries have required only 15 per cent and $\sim 50$ per cent auctioning respectively. ${ }^{143}$ In light of the European experience, the American figure may seem very low, but it reflects the necessary payoffs needed for long-term institutionalisation and policy learning. 144 If the ETS case study is any indication, a move towards general interest equilibriums is possible in America and Australia if policies can clear the first legislative hurdle of institutionalisation:

\footnotetext{
139 M. Grubb, 'Tackling Carbon Leakage: Presentation to Briefing at European Parliament' (Brussels: European Parliament, 2009).

${ }^{140}$ COP-15 coincided with the date for final list adoption of industries at risk of carbon leakage by the commission in December 2009. Article 24 of the Commission Decision triggers a review of the final list if an international agreement is concluded. See n 138 above.

${ }^{141}$ Industry interview; CAN Europe, 'Position paper on Benchmarking and Allocation Rules in Phase III of the EU Emissions Trading System' (Brussels: Climate Action Network Europe, February 2010).

142 J. Wettestad, 'Interaction Between EU Carbon Trading and the International Climate Regime: Synergies and Learning' (2009) 9(4) International Environmental Agreements: Politics, Law and Economics 393, 406.

143 Resources For the Future, 'A Side-by-Side Look at House and Senate Climate Bills' (5 October 2009) at http://www.rff.org/wv/archive/2009/10/05/comparing-house-and-senate-climate-bills.aspx (last visited 20 May 2010); Reuters.com, 'FACTBOX: Australia-EU Carbon Trade Differences' (12 August 2009) at http://www.reuters.com/article/idUSTRE57C0D420090813 (last visited 20 May 2010).

144 Commission interviews; Patashnik, n 55 above, ch 2; B. Lomborg, "The Climate-Industrial Complex: Some Businesses See Nothing but Profits in the Green Movement' (22 May 2009) The Wall Street Journal.
} 
legislation, which at this stage in both countries is uncertain. Indeed America might abandon economy-wide ET entirely in favour of a sectoral approach. ${ }^{145}$

Finally, the analysis also contributes to the debate about regulatory failures and how, from a theoretical perspective, they are manageable by careful selection of MBIs. ${ }^{146}$ The rise of ET was a revolution in European environmental governance. ${ }^{147}$ This upheaval has spread because cost-effective climate mitigation tools are needed by all countries. ${ }^{148}$ Students of history understand that

145 US Congress-House. American Clean Energy and Security Act of 2009. H.R. 2454. 111 th Cong., $1^{\text {st }}$ sess. (26 June 2009) 1-1428 at

http://energycommerce.house.gov/Press_111/20090701/hr2454_house.pdf (last visited 20 May 2010); n 33 above; Parliament of the Commonwealth of Australia, House of Representatives. Carbon Pollution Reduction Bill 2010 (2 February 2010) 1-559 at

http://parlinfo.aph.gov.au/parlInfo/search/display/display.w3p;query=Id\%3A\%22legislation\%2Fbillho me\%2Fr4281\%22 (last visited 20 May 2010). (Also known as the Waxman-Markey Bill).

The Waxman-Markey Bill was passed by the American House of Representatives on June 26, 2009. The original proposal was 600 pages while the final proposal is 1400 pages. It is the product of severe porkbarrelling. The Kerry-Boxer Bill which followed and was before the US Senate in late 2009 provided some improvements (Resources for the Future, n 143 above). In May 2010, Senators Kerry and Lieberman introduced a 987-page bill (n 33 above) that takes a sectoral approach to climate mitigation rather than the economy-wide cap and trade will introduced in the House of Representatives. Cap and trade will apply to electric utilities primarily. However, with the loss of the Democratic Party's supermajority in the Senate and oil spill in the Gulf of Mexico, the passage of this bill by the Senate is uncertain.

A similar pattern has emerged in Australia with their ET legislation: the Carbon Pollution Reduction Scheme (n 143 above). The Green Paper proposals called for auctioning the majority of permits at the outset and eventually moving to $100 \%$ of auctioning, see Department of Climate Change, 'Carbon Pollution Reduction Scheme Green Paper' (Canberra: Commonwealth of Australia, July 2008) at http://www.climatechange.gov.au/ /media/publications/green-paper/greenpaper.ashx (last visited 20 May 2010).

However, various consultations and reiterations of the CPRS legislation have led to very generous provisions made for either free or deferred payments to emissions-intensive-trade exposed industries, the coal and electricity sectors. The actual details of the auctioning process have not been finalised. These generous provisions for polluters partly explain why the CPRS has yet to clear the legislative hurdle: see C. Johnson, 'The CPRS - A Failure of the Left Not Just the Right' (Sydney: OnlineOpinion.com, 2010) at http://www.onlineopinion.com.au/view.asp?article $=10172$ (last visited 20 May 2010); J.C.V. Pezzey, S. Mazouz, and F. Jotzo, 'The Logic of Collective Action and Australia's Climate Policy' (2010) 54 The Australian Journal of Agricultural and Resource Economics 185, 191. See, also, Department of Climate Change, 'Summary Key Changes to the Carbon Pollution Reduction Scheme Legislation' (Canberra: Commonwealth of Australia, May 2009) for a summary of the changes made to the CPRS bill after the public consultations, and Australian Department of Climate Change, 'Details of Proposed CPRS Changes' (Canberra: Commonwealth of Australia, 24 November 2009) for the changes made after negotiations with opposition parties.

The Australian Senate voted down the CPRS Bill on December 2, 2009. The legislation was introduced in the Australian Parliament for a third time on 2 February 2010. In April 2010, the Australian government decided to delay the implementation of the CPRS until after 2012 when the Kyoto Protocol expires. See the Australian Department of Climate Change and Energy Efficiency website for up to date information: http://www.climatechange.gov.au/en/government/initiatives/cprs/cprs-progress.aspx. ${ }^{146}$ Helm, $n 7$ above, 180.

147 CEPS, 'Greenhouse Gas Emissions Trading in Europe: Conditions for Environmental Credibility and Economic Efficiency' (Task Force Report no 43, Brussels: Center for European Policy Studies, 2002) 6.

148 n 1 above, 107. 
revolutions almost always fail to deliver their promises. Many optimists have become ET sceptics because its exposure to rent-seeking may outweigh any benefits. ${ }^{149}$ In light of the result at Copenhagen the prospects for a global carbon market are quite bleak, and there have been renewed calls for a carbon tax instead, or a hybrid approach (with a carbon tax floor for EUA prices), in part because of the high levels of rent-seeking being reported in America and elsewhere. 150 However, the ETS is displaying the green shoots of a restorative order after a policy revolution. With rent-seeking potentially resolvable in the medium term, academic ink can instead address the major issue of governance and enforceability, a more serious 'Achilles Heel', if ET can emerge at a global scale.151

\section{CONCLUSION}

This paper sought to explain the change in EUA allocation rules between ETS phases one and three. It has shown that private interest theories, in addition to their multiple weaknesses, struggle to explain policy change without major shifts in actors' interests, particularly at client politics equilibriums. This is why the hypothesis approached the question through a different analytical framework Wilson's Typology. It presented the argument that the shift from client politics to interest group politics best explains the change in allocation rules between phases one and three.

The ETS case study found evidence of client politics in phase one. This is because the failure of EIIs at differentiation and the resulting windfall profits of generators match Wilson's expectations of higher rent-seeking. Moreover, the change in phase three allocation rules - industry differentiation, use of benchmarking, higher levels of auctioning, and tight exceptions for EIIs - could result in lower rent-seeking, which is consistent with interest group politics expectations. One limitation remains that it is too early to tell whether carbon leakage rules are too lenient, which may undermine the expectation of long-term optimal policy equilibriums.

This paper has significant practical, conceptual, and policy implications. Practically, it provides one of the first factual analyses of phase three's final directive and the first application of Wilson's Typology to both ETS legislative

\footnotetext{
149 n 2 above, 273; D. Helm, 'Rent-Seeking and Picking Winners - UK Climate Policy' (2010) Oxford Review of Economic Policy, forthcoming.

${ }^{150}$ Helm, ibid; Hepburn, n 80 above; R. Falkner, 'Getting a Deal on Climate Change: Obama's Flexible Multilateralism' (2010) January LSE Ideas 37; Financial Times, 'A Changing Corporate Climate' (19 February 2010) Financial Times. N. Robins, R. Clover, et al, 'Flashnote: The Ugly Duckling' (London: HSBC, 2010); Ends Europe, 'EU Must Retain Faith in Emissions Trading - BP' (25 January 2010) at http://www.endseurope.com/23143 (last visited 20 May 2010); PWC, 'Carbon Taxes vs Carbon Trading: Pros, Cons and the Case for a Hybrid Approach' (London: Price Waterhouse Coopers, March 2009).

151 Baldwin, n 2 above 272; R.N. Stavins, 'Implications of the US Experience with Market-Based Environment Strategies for Future Climate Policy' in B. Hansjürgens (ed), Emissions Trading for Climate Policy: US and European Perspectives (Cambridge: Cambridge University Press, 2005) 72.
} 
phases. Conceptually, the ETS case study demonstrates shifts between client and interest group politics, an area largely ignored by the literature. Despite the methodological limitations, an important theoretical lesson can be drawn: information asymmetry between lobbying groups during new, complex, and rushed policymaking can force client politics outcomes in otherwise interest group scenarios. This empirical reality can be reconciled with Wilson's Typology by understanding his idea of regulatory costs and benefits in a broader sense to include: transaction, collective action, and informational costs and benefits. From a policy perspective, useful lessons can also be drawn about the evolution of ET. Most importantly, this paper identifies the potential for ET reforms to reach longterm general interest equilibriums after false starts. This very preliminary analysis provides a framework that will hopefully be validated by future research. Global climate policy could hang in the balance. 


\section{APPENDIX ONE}

LOBBYING POSITIONS IN BOTH ETS PHASES

Table Four: Positions of EURELECTRIC and AEIIs in ETS phases one and three ${ }^{152}$

\begin{tabular}{|c|c|c|}
\hline & EURELECTRIC & AEIIs \\
\hline $\begin{array}{l}\text { Phase } \\
\text { one }\end{array}$ & $\begin{array}{l}\text { Sector targets: Believe that } \\
\text { generators should not be the sole } \\
\text { target } \\
\text { Enforcement: Favor a voluntary } \\
\text { cap and trade system } \\
\text { Allocation: Favor grandfathering } \\
\text { based on historical emissions by } \\
\text { member states }\end{array}$ & See Table Five \\
\hline $\begin{array}{l}\text { Phase } \\
\text { three }\end{array}$ & $\begin{array}{l}\text { Sector target: Favor all gases and } \\
\text { sectors. Opposed to excluding } \\
\text { small installations because of } \\
\text { market distortions. } \\
\text { Allocation: If increased auctioning } \\
\text { is inevitable then all sectors should } \\
\text { be treated equally. Auctioning } \\
\text { should be harmonised at the EU } \\
\text { level } \\
\text { Redistribution of auctioning } \\
\text { revenues should avoid creating } \\
\text { market distortions. } \\
\text { Oppose any allocation that } \\
\text { discriminates against the electricity } \\
\text { sector but favor principled } \\
\text { exceptions (demonstrated by } \\
\text { robust evidence) for industries at } \\
\text { risk of carbon leakage until a } \\
\text { global emission trading regime is } \\
\text { established. }\end{array}$ & $\begin{array}{l}\text { Sector target: Favor redesigning } \\
\text { ETS to create an EU and global } \\
\text { level playing field. } \\
\text { Support the exclusion of small } \\
\text { installations. Also favor a sectoral } \\
\text { and performance-based } \\
\text { allocation approach for energy } \\
\text { intensive industries and large } \\
\text { emitting homogenous processes. } \\
\text { Allocation: Against auctioning } \\
\text { for EIIs because of risk of } \\
\text { carbon leakage. Favor linking } \\
\text { allocation to ambitious } \\
\text { benchmarks. } \\
\text { Criteria for identifying firms that } \\
\text { qualify should be fair, } \\
\text { transparent, and objective. } \\
\text { Qualitative factors should be } \\
\text { added to Commission Directive two. }\end{array}$ \\
\hline
\end{tabular}

152 Source: n 75 above; n 77 above; AEII, 'Position of Energy Intensive Industries Alliance and the Alliance for a Competitive Industry for the EU ETS Review' (2 December 2008) at http://pr.euractiv.com/node/7388 (last visited 20 May 2010). 


\begin{tabular}{|l|l|l|}
\hline $\begin{array}{l}\text { Electricity prices: Against } \\
\text { government intervention in } \\
\text { electricity prices that undermines } \\
\text { the EU ETS (higher prices) and } \\
\text { liberalisation process. Also against } \\
\text { regulation of electricity generator } \\
\text { profits and taxation of low-carbon } \\
\text { generation. }\end{array}$ & $\begin{array}{l}\text { Electricity prices: Favor } \\
\text { regulating electricity prices for } \\
\text { EIIs or offsetting } \mathrm{CO}_{2} \text { pass- } \\
\text { through costs using taxation for } \\
\text { all sectors. }\end{array}$ \\
& $\begin{array}{l}\text { Other: } \\
\text { Favor abandoning the option of } \\
\text { reduced-production as a means } \\
\text { of lowering GHG emissions in } \\
\text { Europe. Also favor ending } \\
\text { distortions of the free market } \\
\text { and preventing further unequal } \\
\text { treatment for new entrants } \\
\text { versus incumbents. }\end{array}$ \\
\hline
\end{tabular}

Table Five: Positions of AEIIs in phase one $e^{153}$

\author{
Abbreviations \\ ACEA: European Automobile Manufacturers \\ CEFIC: The European Chemical Industry Council \\ CEMBUREAU: The European Cement Association \\ CEPF: Confederation of European Forest Owners \\ CEPI: Confederation of European Paper Industry \\ CERAMIE-UNIE: The liaison office for the European Ceramic Industry \\ CIAA: European Food and Drink Industries \\ CPIV: the European Glass Industry \\ EEA: European Aluminium Association \\ EEF: the British Manufacturers' Organisation \\ EISA: European Independent Steel Works Association \\ EULA: European Lime Association \\ EUROALLIAGES: European Ferro-Alloy Industry Association \\ EUROFER: European Confederation of Iron and Steel Industries \\ EUROMETAUX: Association representing the European non-ferrous metals \\ industry \\ EUROPIA: European Petroleum Industry Association \\ EXCA: European Expanded Clay Industry Association \\ IFIEC: International Federation of Industrial Energy Consumers \\ OGP: International Association of Gas and Oil Producers \\ UNICE: Union des Industries de la Communauté européenne
}

153 Source: n 75 above. 


\begin{tabular}{l} 
AEIIs \\
\hline Sector target: \\
- UNICE and IFIEC wanted as many sectors and gases to create as much \\
flexibility and liquidity as possible to minimise effects on European and \\
international competitiveness \\
-EUROPIA and OGP: All sectors \\
-EUROFER and EISA: EIASA against ETS, but EUROFER wants all sectors \\
-CEPI and CEPF: All sectors and include transport \\
-CEMBUREAU and CERAMIE-UNIE: Same sectors should be covered in all \\
members states \\
-CEFIC: Wanted chemical industry excluded from ETS \\
-EUROMETAUX and EEA: Wanted aluminum industry excluded from ETS \\
but as many others included \\
Enforcement: \\
- UNICE and IFIEC: The latter wanted voluntary opt-in and out, the former is \\
silent \\
-EUROPIA and OGP: Voluntary until 2008 no possibility of opt-out \\
-EUROFER and EISA: Voluntary \\
- CEPI and CEPF: Voluntary \\
-CEMBUREAU and CERAMIE-UNIE: Voluntary start in 2005 no possibility \\
of opt-Out \\
-CEFIC: Voluntary \\
-EUROMETAUX and EEA: Voluntary with opt-out
\end{tabular}

Allocation:

- UNICE and IFIEC: Both unclear but preference for member state allocation -EUROPIA and OGP: Free with a preference for Community level oversight and guidelines

- EUROFER and EISA: The former: favor relative targets by benchmarking and negotiated agreements at the EU level to avoid competitive distortions. The latter: in favor of auctioning

-CEPI and CEPF: The former: Grandfathering based on common baseline. Targets set by negotiation, allocation by member states but with harmonisation of rules and compliance at community level. The latter: not specific.

-CEMBUREAU and CERAMIE-UNIE: The latter: in favor of auctioning but unclear about EU role other than trading should be operational internationally. The former: against with EU role in harmonisation

-CEFIC: Free member state allocation and based on negotiated agreements with trade associations

-EUROMETAUX and EEA: No allowances, instead industry targets should be established, unclear on EU role although implicit that sectors means community level 
COMMISSION PROPOSALS AND DIRECTIVES

Table Six: Phase one comparison of Green Paper and final directive ${ }^{154}$

\begin{tabular}{|c|c|c|}
\hline & Green Paper & Directive One \\
\hline $\begin{array}{l}\text { Sector } \\
\text { target }\end{array}$ & $\begin{array}{l}6 \text { GHG } \\
\text { Feasibility of energy generators } \\
>50 \mathrm{MWth} \\
\text { Iron, steel, minerals, cement, } \\
\text { pulp and paper, refineries, } \\
\text { aluminum, chemical } \\
\text { Opt-in and Opt-out (i.e. } \\
\text { voluntary or mandatory) }\end{array}$ & $\begin{array}{l}\text { Article } 2 \text { (1) and Annex I \& II: } \\
\mathrm{CO}_{2} \text {. But other gases if possible } \\
\text { (Article 24) } \\
\text { Article } 2 \text { (1) and Annex I: } \\
\text { Energy generators > 20MWth } \\
\text { Article } 2 \text { (1) and Annex I: Iron, } \\
\text { steel, minerals, cement, pulp and } \\
\text { paper, refineries. Aluminum, } \\
\text { chemical if possible } \\
\text { Article 27: Mandatory. But opt- } \\
\text { in for installations below level in } \\
\text { directive, temporary opt-out for } \\
\text { installations }\end{array}$ \\
\hline $\begin{array}{l}\text { Initial } \\
\text { allocation }\end{array}$ & $\begin{array}{l}\text { For free/grandfathering } \\
\text { Preference for auctioning } \\
\text { Preference for allocation by } \\
\text { EU } \\
\text { Allocation by MS-EU } \\
\text { rules/guidelines for allocation }\end{array}$ & $\begin{array}{l}\text { Article 10: } 95 \% \text { and } 90 \% \text { for } \\
\text { free in phase one and phase two } \\
\text { respectively } \\
\text { Article 9: Allocation by } \\
\text { member states, EU can reject } \\
\text { according to Internal Market } \\
\text { Rules and allocation to follow } \\
\text { Burden Sharing path }\end{array}$ \\
\hline
\end{tabular}

${ }^{154}$ Source: $\mathrm{n} 70$ above; $\mathrm{n} 68$ above; Markussen and Svendsen, n 6 above, 256. 
Table Seven: Phase three comparison of Commission Proposal Two with Directive Two ${ }^{155}$

\begin{tabular}{|c|c|c|}
\hline & $\begin{array}{c}\text { Commission Proposal } \\
\text { Two }\end{array}$ & Directive Two \\
\hline Sector targets & $\begin{array}{l}\text { New gases: N20 and } \\
\text { perfluorocarbons } \\
\text { New sectors: petrochemicals, } \\
\text { ammonia, aluminum, acid } \\
\text { (nitric, adipic, glyoxylic) } \\
\text { Aviation is covered in a } \\
\text { separate proposal156 } \\
\text { Excluded small installations } \\
<25 \mathrm{MW} \text { and lower than } \\
10,000 \text { tones of } \mathrm{CO}_{2} \text { for each } \\
\text { of last three years }\end{array}$ & $\begin{array}{l}\text { Annex I \& II } \\
\text { Same, but also includes: } \\
\text { carbon capture, transport } \\
\text { and geological storage of all } \\
\text { greenhouse gas emissions } \\
\text { Aviation included as of } 2012 \\
\text { (Separate Directive }^{157} \text { ) } \\
\text { Excluded small installations: } \\
<35 \mathrm{MW} \text { and lower than } \\
25,000 \text { tones each of last } \\
\text { three years. }\end{array}$ \\
\hline $\begin{array}{l}\text { Total level of } \\
\text { auctioning }\end{array}$ & $\begin{array}{l}\text { Phase three estimate: } 66 \% \\
100 \% \text { auctioning in all } \\
\text { sectors by } 2020 \text { (with } \\
\text { exception for industries at } \\
\text { risk of carbon leakage) }\end{array}$ & $\begin{array}{l}\text { Phase three estimate: } 50 \% \\
100 \% \text { auctioning in all } \\
\text { sectors by } 2027 \text { (with } \\
\text { exception for industries at } \\
\text { risk of carbon leakage) }\end{array}$ \\
\hline $\begin{array}{l}\text { Allocation for } \\
\text { generators }\end{array}$ & $100 \%$ auctioning & $\begin{array}{l}\text { Article } \mathbf{1 0} \text { (c) } \\
\text { Option for Members State } \\
\text { derogation of } 100 \% \\
\text { auctioning if satisfy test: }(1) \\
\text { level of interconnectivity; or } \\
\text { (2) } \% \text { fossil fuel generation. } \\
\text { Derogations require } \\
\text { minimum } 30 \% \text { auctioning } \\
\text { and full auctioning by } 2020\end{array}$ \\
\hline $\begin{array}{l}\text { Allocation for } \\
\text { EIIs }\end{array}$ & $\begin{array}{l}\text { Free but subject to review } \\
\text { after Copenhagen COP } 15\end{array}$ & $\begin{array}{l}\text { Article } 10 \text { (b) } \\
\text { Free but subject to review } \\
\text { after Copenhagen COP } 15\end{array}$ \\
\hline
\end{tabular}

155 Source: $\mathrm{n} 73$ above; n 74 above, n 124 above; Commission (EC), 'Questions and Answers on the Revised EU Emissions Trading System’ (Memorandum) MEMO/08/796, 17 December 2008.

${ }_{156}$ Commission (EC), Proposal for a Directive of the European Parliament and of the Council Amending Directive 2003/87/EC so as to Include Aviation Activities in the Scheme for Greenhouse Gas Emission Allowance Trading Within the Community' (Communication) COM (2006) 818 final, 20 December 2006.

157 Parliament and Council Directive (EC) 2008/101 Amending Directive 2003/87/EC so as to Include Aviation Activities in the Scheme for Greenhouse Gas Emission Allowance Trading Within the Community [2009] OJ L8/3. 


\begin{tabular}{|c|c|c|}
\hline $\begin{array}{l}\text { Methodology } \\
\text { for } \\
\text { Identification } \\
\text { of Industries at } \\
\text { risk of } \\
\text { significant } \\
\text { carbon leakage }\end{array}$ & $\begin{array}{l}\text { Not detailed: } \\
\text { 'inability to pass through the } \\
\text { cost of required allowances } \\
\text { in product prices without } \\
\text { significant loss of market } \\
\text { share to installations outside } \\
\text { the EU not taking } \\
\text { comparable action to reduce } \\
\text { emissions'. }\end{array}$ & $\begin{array}{l}\text { Article } 10 \text { (a) } \\
\text { More detailed: direct and } \\
\text { indirect additional } \\
\text { production costs as a } \\
\text { proportion of gross value } \\
\text { added exceed } 5 \% \text { and } \\
\text { whether total value of its } \\
\text { exports and imports divided } \\
\text { by the total value of its } \\
\text { turnover exceeds } 10 \% \text {. If } \\
\text { the result of either of these } \\
\text { criteria exceeds } 30 \% \text {, a sector } \\
\text { is considered at risk of } \\
\text { significant carbon leakage. }\end{array}$ \\
\hline $\begin{array}{l}\text { Compensation } \\
\text { for electricity } \\
\text { price pass- } \\
\text { through }\end{array}$ & No provision & $\begin{array}{l}\text { Article 10(a) } \\
\text { Compensation for costs } \\
\text { relating to greenhouse gas } \\
\text { emissions passed through in } \\
\text { electricity costs. } \\
\text { This will be subject to } \\
\text { modified state aide rules. } \\
\text { Based on ex ante } \\
\text { benchmarks of electricity } \\
\text { consumption per unit of } \\
\text { output based on best } \\
\text { available technology and } \\
\mathrm{CO}_{2} \text { emissions of the } \\
\text { relevant European electricity } \\
\text { production mix. }\end{array}$ \\
\hline $\begin{array}{l}\text { Provisions for } \\
\text { new market } \\
\text { entrants }\end{array}$ & $\begin{array}{l}5 \% \text { of the total quantity of } \\
\text { allowance will be put into } \\
\text { reserve for new installations } \\
\text { or airlines that enter the } \\
\text { system after } 2013 \text {. } \\
\text { Allocation from this reserve } \\
\text { will mirror rules for } \\
\text { allocation corresponding to } \\
\text { existing installations or } \\
\text { sectors } \\
\text { Remaining allowances will be } \\
\text { distributed to Member states } \\
\text { for auctioning. The } \\
\text { distribution key is the same }\end{array}$ & $\begin{array}{l}\text { Article } \mathbf{1 0}(\mathbf{a}) \\
\text { Same except: } \\
\text { A part of new entrant } \\
\text { reserve, amounting to } 300 \\
\text { million allowances will be } \\
\text { made available to support } \\
\text { the investments in up to } 12 \\
\text { demonstration projects using } \\
\text { the carbon capture and } \\
\text { storage technology and } \\
\text { demonstration projects using } \\
\text { innovative renewable energy } \\
\text { technologies. } \\
\text { Remaining allowance }\end{array}$ \\
\hline
\end{tabular}




\begin{tabular}{|l|l|l|}
\hline & $\begin{array}{l}\text { as for all other allowances to } \\
\text { be auctioned. }\end{array}$ & $\begin{array}{l}\text { distribution will take into } \\
\text { account the level to which } \\
\text { installations in Member } \\
\text { states benefited from the } \\
\text { reserve. }\end{array}$ \\
\hline
\end{tabular}

\section{APPENDIX TWO}

Members of THE AEII on 2 DeCEMBer 2008158

\begin{tabular}{|l|l|}
\hline ACEA & EULA \\
CEFIC & EUROALLIAGES \\
CEMBUREAU & EUROFER \\
CEPI & EUROMETAUX \\
CERAME UNIE & EUROPIA \\
CIAA & EXCA \\
CPIV & IFIEC \\
\hline
\end{tabular}

\section{AEII PRESS RELEASES}

AEII, 'Energy Intensive Industries Call Upon EU Decision-Makers to Pay More Attention to the Impact of Emissions Trading Upon their Competitiveness' (1 January 2004) at http://www.cembureau.be/Cem_warehouse/1-

ENERGY\%20INTENSIVE\%20INDUSTRIES-JANUARY\%202004.PDF (last visited 1 August 2009)

AEII, 'Joint Statement: Power Intensive Industries Object to Windfall Profits from Emissions Trading' (11 March 2004) at http://www.cembureau.be/Cem_warehouse/2INDIRECT\%20IMPACT\%20OF\%20EMISSIONS\%20TRADING\%20ON\%20 ELECTRICITY\%20PRICES.PDF (last visited 1 August 2009)

AEII, 'Energy Intensive Industries Reject the Inclusion of Aviation in the Emission Trading Scheme' (October 2005) at

\footnotetext{
158 Source: AEII, Position of Energy Intensive Industries Alliance and the Alliance for a Competitive Industry for the EU ETS Review' (2 December 2008) at http://pr.euractiv.com/node/7388 (last visited 20 May 2010).
} 
http://www.cembureau.be/Cem_warehouse/AVIATION\%20-

\%20FINAL\%20POSITION\%20PAPER\%20-\%20EII.PDF (last visited 1 August 2009)

AEII, The Impact of EU Emission Trading Scheme (ETS) on Power Prices: Remedial Action Urgently Needed 10 Months After Start of ETS' (November 2005) at

http://www.cembureau.be/Cem_warehouse/ALLIANCE\%20ETS\%20AND\%20 POWER\%20PRICES.PDF (last visited 1 August 2009)

AEII, 'Contribution to the EU Energy Strategic Review Urgent Measures are Required to Improve the Functioning of Electricity and Gas Markets: The Alliance of Energy-Intensive Industries Proposes a Set of Solutions' (22 September 2006) at

http://www.euractiv.com/29/images/Alliance $\% 20$ EII $\% 20$ Energy $\% 20$ Strategic $\%$ 20Review\%20position_tcm29-160900.doc (last visited 20 May 2010)

AEII, 'Position Paper of the Alliance of Energy Intensive Industries on "Further Guidance on Allocation Plans for 2008 to 2012' (17 February 2006) at http://www.cembureau.be/Cem_warehouse/AEII-FINAL\%20POSITIONGUIDANCE\%20ON\%20ALLOCATION\%20PLANS2008\%20TO\%202012.PDF (last visited 1 August 2009)

AEII, 'Lowering Production is No Benefit for the Environment, Says European Industry' (21 May 2007) at http://www.cembureau.be/Cem_warehouse/LOWERING\%20PRODUCTION \%20IS\%20NO\%20BENEFIT.PDF (last visited 1 August 2009)

AEII, 'Key Messages on the Emissions Trading Scheme Review' (May 2008), at http://www.eula.be/EULA/pixdyn00.nsf/0/CC786F2150045B1DC12574500026 D536/\$File/2008-05-

20\%20AEII\%20joint $\% 20$ position $\% 20$ on $\% 20$ ETS $\% 20$ Review.pdf (last visited 1 August 2009)

AEII, 'Letter to Commissioners for EU ETS Review' (11 January 2008) at http://www.endseurope.com/docs/80115b.pdf (last visited 20 May 2010)

AEII, 'Position of Energy Intensive Industries Alliance and the Alliance for a Competitive Industry for the EU ETS Review' (2 December 2008) at http://pr.euractiv.com/node/7388 (last visited 20 May 2010) 


\section{APPENDIX THREE}

\section{INTERVIEWS}

\section{Industry}

Interview 1: Representative of the Bryman Partnership: Business \& Environmental Consultancy, representing the Confederation of Paper Industries at the UK Emissions Trading Group, 10 July 2009: 14:00, London, and 20 December 2009: 17:00, London.

Interview 2: Representative of the Environmental Analyst Team, British Energy, 5 June 2009: 17:00, London.

Interview 3: Executive at EDF Energy, 5 June 2009: 16:30, London.

Interview 4: Representative for Strategy and Sustainable Development, EDF Energy, 5 June 2009: 17:15, London.

Interview 5: Representative of EEF: the Manufacturers' Organisation, 4 August 2009: 10:00, London.

\section{Commission}

Interview 1: Senior official at the Directorate-General for the Environment, European Commission, 5 June 2009: 11:30, London.

Interview 2: Official at Directorate B - Industrial Policy and Economic Reform: Directorate-General for Enterprise and Industry, European Commission, 2 June 2009: 09:00, Brussels.

Interview 3: Official at Unit for market based instruments including Greenhouse gas emissions trading: Directorate-General for the Environment, European Commission, 2 June 2009: 14:30, Brussels.

Interview 4: Official at Unit A1 Economic Analysis, Impact Assessment, Evaluation and Climate Change: Directorate General Energy and Transport, European Commission, 2 July 2009: 09:00, Brussels. 